\title{
Ethynodiol Diacetate
}

National Cancer Institute

\section{Source}

National Cancer Institute. Ethynodiol Diacetate. NCI Thesaurus. Code C47525.

The diacetate salt form of ethynodiol, a semi-synthetic progestational hormone agonist.

Ethynodiol diacetate binds to cytoplasmic progesterone receptors in the reproductive system and subsequently activates progesterone receptor mediated gene expression. As a result of the negative feedback mechanism, luteinizing hormone $(\mathrm{LH})$ release is inhibited, which leads to an inhibition of ovulation and an alteration in the cervical mucus and endometrium. In addition, ethynodiol diacetate has weak oestrogenic and androgenic properties. 